Erratum

\title{
Erratum: Wang et al. Urbanization Impacts on Natural Habitat and Ecosystem Services in the Guangdong-Hong Kong-Macao "Megacity". Sustainability 2020, 12, 6675
}

\author{
Wenjing Wang ${ }^{1,2}$, Tong Wu ${ }^{1}$, Yuanzheng $\mathrm{Li}^{3}{ }^{3}$, Shilin Xie ${ }^{1,2}$, Baolong Han ${ }^{1}$, Hua Zheng ${ }^{1}$ and Zhiyun Ouyang ${ }^{1, *(D)}$ \\ 1 State Key Laboratory of Urban and Regional Ecology, Research Center for Eco-Environmental Sciences, \\ Chinese Academy of Sciences, Beijing 100085, China; wjwang_st@rcees.ac.cn (W.W.); \\ tongwu15@outlook.com (T.W.); slxie_st@rcees.ac.cn (S.X.); blhan@rcees.ac.cn (B.H.); \\ zhenghua@rcees.ac.cn (H.Z.) \\ 2 College of Resources and Environment, University of Chinese Academy of Sciences, Beijing 100049, China \\ 3 School of Resources and Environment, Henan University of Economics and Law, Zhengzhou 450046, China; \\ yzli_pili@outlook.com \\ * Correspondence: zyouyang@rcees.ac.cn
}

Citation: Wang, W.; Wu, T.; Li, Y.; Xie, S.; Han, B.; Zheng, H.; Ouyang, Z. Erratum: Wang et al. Urbanization Impacts on Natural Habitat and Ecosystem Services in the Guangdong-Hong Kong-Macao "Megacity". Sustainability 2020, 12, 6675. Sustainability 2021, 13, 4580. https://doi.org/10.3390/su13084580

Received: 12 April 2021 Accepted: 13 April 2021 Published: 20 April 2021

Publisher's Note: MDPI stays neutral with regard to jurisdictional claims in published maps and institutional affiliations.

Copyright: (c) 2021 by the authors. Licensee MDPI, Basel, Switzerland. This article is an open access article distributed under the terms and conditions of the Creative Commons Attribution (CC BY) license (https:// creativecommons.org/licenses/by/ $4.0 /)$.
The authors would like to make the following correction about the published paper [1]. The change is as follows:

Replacing affiliation 2:

State Key Laboratory of Urban and Regional Ecology, University of Chinese Academy of Sciences, Beijing 100049, China with

College of Resources and Environment, University of Chinese Academy of Sciences, Beijing 100049, China

The authors and the Editorial Office would like to apologize for any inconvenience caused to the readers and state that the scientific conclusions are unaffected. The original article has been updated.

\section{Reference}

1. Wang, W.; Wu, T.; Li, Y.; Xie, S.; Han, B.; Zheng, H.; Ouyang, Z. Urbanization Impacts on Natural Habitat and Ecosystem Services in the Guangdong-Hong Kong-Macao "Megacity". Sustainability 2020, 12, 6675. [CrossRef] 